\title{
Famari (Penghinaan Berujung Pada Tradisi Yang Mampu Menyebabkan Sanksi/Denda Adat, Tradisi Pada Masyarakat Misool Barat, Kepulauan Raja Ampat)
}

\author{
Muhamad Yusuf ${ }^{1 *}$, Muhammad Syukri Nawir ${ }^{2}$ \\ 1, 2 Institut Agama Islam Negeri Fattahul Muluk Papua, Jayapura, Indonesia \\ *E-mail: joesoef1974@gmail.com
}

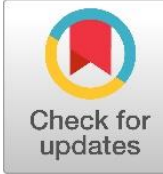

Dikirim: $31 / 12 / 2019$

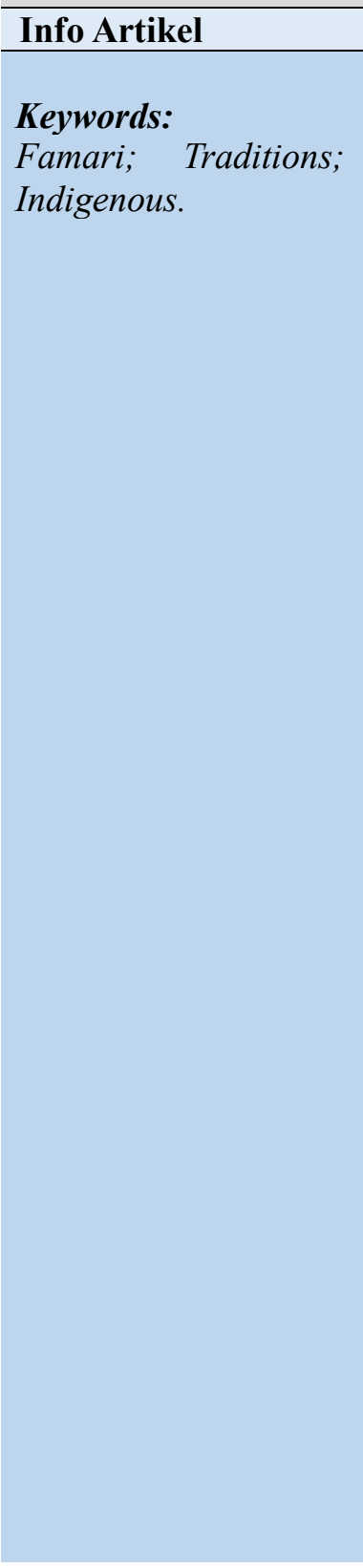

Direvisi: $26 / 10 / 2020$

Dipublikasi: 24/3/2021

\section{Abstract}

One of the traditions that exist in the people of the West Misool islands is the Famari tradition. This tradition is usually carried out when someone from another village humiliates people from another village. This tradition is a tradition from generation to generation, but is only an oral story and has never been written into a written story. This study aims to determine the implementation model of the Famari tradition in communities in West Misool District, Raja Ampat Islands, and the methods used by indigenous peoples to maintain the Famari tradition in West Misool District, Raja Ampat Islands. This research is a qualitative descriptive study using a social phenomenological paradigm. Sources of data for analyzing research problems were obtained from two sources, namely: primary data and secondary data. The results show that the origin of the Famari tradition was created by the ancestors of the West Misool community in creating order, in which there are universal values such as the principle of mutual cooperation, human social function and property in society, consent as a general power, the principle of representation and deliberation. What causes the emergence of the Famari tradition is that in restoring moral balance, it creates collective awareness from community groups to neutralize differences. The Famari tradition does not see the time when it must be carried out, the form of fines in the Famari tradition is determined based on an agreement, the number of people who follow the tradition has no clear limit. Customary fines payment techniques in the Famari tradition are carried out after the party. Without an official invitation, residents came and got involved, to take part in Famari activities. The Famari tradition was created to avoid degrading other social groups, where there are sanctions as punishment for those who are guilty and restore moral balance in society. 
Kata Kunci:

Famari; Tradisi; Adat.

DOI:

10.47268/sasi.v27i1.225

\begin{abstract}
Abstrak
Salah satu tradisi yang ada pada masyarakat kepulauan Misool Barat adalah tradisi Famari. Tradisi ini biasa dilakukan ketika seseorang dari Kampung lain mempermalukan orang dari Kampung lainnya, Tradisi ini merupakan tradisi secara turun temurun, akan tetapi hanya sebuah cerita lisan dan tidak pernah dituangkan kedalam cerita tertulis. Penelitian ini bertujuan untuk mengetahui model pelaksanaan tradisi Famari pada masyarakat di Distrik Misool Barat, kepulauan Raja Ampat, dan cara yang digunakan masyarakat adat mempertahankan tradisi Famari di Distrik Misool Barat, kepulauan Raja Ampat. Penelitian ini merupakan penelitian deskriptip kualitatif menggunakan paradigma fenomenologis Sosial. Sumber data untuk menganalisis permasalahan penelitian diperoleh dari dua sumber yaitu : data primer dan data sekunder. Hasil penelitian menunjukan bahwa asal muasal tradisi Famari diciptakan oleh leluhur masyarakat Misool Barat dalam menciptakan ketertiban, di dalamnya terdapat nilai universal seperti asas gotong royong, fungsi sosial manusia dan milik dalam masyarakat, persetujuan sebagai kekuasaan umum, asas perwakilan dan permusyawaratan. Yang menyebabkan munculnya tradisi Famari adalah dalam mengembalikan keseimbangan moral menimbulkan kesadaran kolektif dari kelompok masyarakat untuk menetralisir perbedaan. Tradisi Famari tidak melihat waktu kapan harus dilaksanakan, bentuk denda dalam tradisi Famari ditetapkan berdasarkan kesepakatan, jumlah masyarakat yang mengikuti tradisi tidak terdapat batasan yang jelas. Tehnik pembayaran denda adat dalam tradisi Famari dilakukan setelah berlangsungnya pesta. Tanpa undangan resmi, warga datang dan melibatkan diri, untuk ikut dalam kegiatan Famari. Tradisi Famari diciptakan untuk menghindarkan dari tabiat merendahkan kelompok masyarakat lainnya, dimana terdapat sanksi sebagai hukuman bagi yang bersalah dan mengembalikan keseimbangan moral dalam masyarakat.
\end{abstract}

\section{A. PENDAHULUAN}

Kepulauan Raja Ampat merupakan satu gugusan kepulauan yang ada di Propinsi Papua Barat, yang merupakan Kabupaten tersendiri yaitu Kabupaten Raja Ampat, dimana terdiri dari beberapa pulau besar dan kecil, yang memiliki budaya yang beraneka ragam, yang belum di eksplor ke dunia luar. Kepulauan Raja Ampat terbentuk dari pulau-pulau besar dn kecil. Adapun pulau-pulau besar terdiri dari Waigeo, Salawati, Misool dan Batanta, dalam kehidupan masyarakat Kepulauan Raja Ampat mereka lebih mudah menerima orang dari luar dibandingkan dengan wilayah Papua lainnya, karena telah mengalami pengembangan peradaban lebih dahulu dibandingkan wilayah Papua lainnya.

Tradisi yang beraneka ragam juga terdapat diwilayah Distrik Misool Barat, dimana berbagai tradisi masyarakat dilakukan dalam kehidupan sehari-hari. Salahsatu tradisi yang ada pada masyarakat kepulauan Misool adalah tradisi Famari dimana tradisi ini dilakukan oleh masyarakat Misool Barat. Tradisi ini biasa dilakukan ketika seseorang dari Kampung lain mempermalukan orang dari Kampung lainnya, misalkan saja ketika seseorang dari Kampung lain mengatakan bahwa orang dari Kampung lainnya tidak mampu memberikan makan ikan kepadanya, maka orang dari Kampung tersebut secara bersama-sama menyiapkan ikan sebanyak mungkin dan mengundang orang tersebut beserta teman-teman, kerabat dan keluarganya untuk menghabiskan ikan yang telah disiapkan. Ketika mereka tidak mampu menghabiskan ikan tersebut, maka orang dari Kampung lain tersebut harus membayar kepada orang yang memberikan makan sejumlah uang yang telah ditetapkan sebelumnya sebagai denda yang harus dibayarkan. Biasanya dilakukan antara kaum laki-laki dengan kaum perempuan. Tradisi ini dilakukan masyarakat adat hingga kini menjadi tradisi yang dilakukan secara turun temurun oleh warganya, tetapi berbagai tradisi tersebut hanya sebuah cerita lisan dan tidak 
pernah dituangkan kedalam sebuah cerita tertulis.

Literatur review: Abdul Rahman, Jamhuri, Irwansyah, mengatakan: Sanksi adat Kampung Taman Firdaus mengenai kekerasan fisik yaitu denda satu ekor kambing untuk luka di kepalayang darahnya mengalir, serta denda satu ekor ayam untuk luka di kepala yang darahnya keluar tidak mengalir, sehingga sanksi adat mengenai kekerasan fisik atas objek ini sesuai dengan hukum pidana Islam, sebab dalam hukum Islam menyatakan bahwa luka di kepala yang mengalir darahnya, dan luka di kepala yang darahnya tidak mengalir sanksinya adalah hukumah (ganti rugi yang besarnya diserahkan kepada keputusan hakim). ${ }^{1}$

Yogi Hardiman, Siti Kotijah, La Sina, mengatakan : Penyelesaian adat atas tindak pidana yang telah diberikan sanksi adat oleh suku DayakWehea berdasarkan hukum adat, menjadi dasar pihak Kepolisian menerapkan restorative justice terhadap pelaku tindak pidana ringan yang telah dijatuhi sanksi adat di Satuan Reserse Kriminal Kepolisian Resor Kutai Timur yang merupakan role model dalam proses penyelesaian sengketa diluar pengadilan, yang mampu memberikan efisiensi serta kepastian hukum pada korban serta pelaku tidak pidana ringan. ${ }^{2}$

Asep Dewantara, yang menguji teori Ajip Rosidi mengenai Perubahan Sosial Budaya melalui data lapangan atau secara empiris serta untuk mengungkapkan nilai budaya dalam adat istiadat atau kearifan lokal di Kampung Adat Urug dan memaparkan peran ketua adat sebagai elit masyarakat dalam menjaga keberlangsungan adat. Subjek kajiannya adalah masyarakat kontemporer di Kampung adat Urug, Desa Kiarapandak, Kecamatan Sukajaya kabupaten Bogor, terutama ketua adat yang berjumlah tiga orang dan sebagian warga sebagai informan ${ }^{3}$.

Ayatullah Humaeni, mengatakan: Keberadaan tabu perempuan dalam budaya Banten yang mempunyai pengaruh terhadap kehidupan sosial keagamaan masyarakat Banten. Jika menganalisis isi dan makna tabu berdasarkan konteks sosial kulturalnya memiliki fungsi serta makna sebagai bentuk penjagaan moral dan perilaku pemeliharaan identitas diri juga identitas sosial, memperkuat hubungan emosional, bentuk perlindungan, sampai simbol kasih saying dan cinta $^{4}$.

Anwar Sadat Harahap, Ahmad Laut Hasibuan, Taufik Siregar, yang mengatakan bahwa : Dalam setiap pelanggaran atau kejahatan yang dilakukan pada masyarakat, telah ada aturanan tentang pemberlakuan sanksi yang tertuang dalam Surat Tumbaga Holing dan menjadi sumber rujukan hukum adat masyarakat adat Batak Bagian Selatan. Di Dalam surat tersebut, terdapat beberapa sanksi yang mengandung kearifan lokal yang dijatuhkan kepada orang yang memicu timbulnya konflik sosial dalam masyarakat. ${ }^{5}$

Agnesia Hartini dan Veronoka Linda mengatakan bahwa: Penjatuhan sanksi adat yang sering sekali terjadi ketidak konsistenan, sehingga masyarakat hukum adat merasa tidak puas, dimana hukum adat mampu menjadi pegangan karena bersifat tidak adil dan tidak konsisten hal ini dikarenakan belum adanya pembukuan yang dibuat secara khusus tentang sanksi adat. ${ }^{6}$

\footnotetext{
${ }^{1}$ Rahman, Abdul., Jamhuri., Irwansyah. (2018), Sanksi Adat Bagi Pelaku Kekerasan Fisik Ditinjau Menurut Hukum Pidana Islam. Jurnal Petita, 3 (2), 137-144. https://doi.org/10.22373/petita.v3i2.49

${ }^{2}$ Hardiman, Yogi., Kotijah, Siti., Sina, La. (2019). Restorative Justice Terhadap Pelaku Tindak Pidana Ringan Yang Telah Diberi Sanksi Adat. Mulawarman Law Review. 14 (1), 29-43. https://doi.org/10.30872/mulrev.v4i1.48

${ }^{3}$ Dewantara, Asep. (2013). Peran Elit Masyarakat: Studi Kebertahanan Adat Istiadat di Kampung Adat Urug Bogor, Buletin Al-Turas, 19 (1), 89-117. https://doi.org/10.15408/bat.v19i1.3703

${ }^{4}$ Humaeni, Ayatullah. (2015). Tabu Perempuan Dalam Budaya Masyarakat Banten. Jurnal Humaniora, 27 (2), 174-185. https://doi.org/10.15408/bat.v19i1.3703.

${ }^{5}$ Harahap, Anwar Sadat., Hasibuan, Ahmad Laut., Siregar, Taufik. (2018). Kearifan Lokal Dalam bentuk Sanksi Hukum Bagi Pelanggar Pada Masyarakat Adat Batak Bagian Selatan. Anthropos: Jurnal Antropologi Sosial dan Budaya, 3 (2), 122-130. https://doi.org/10.24114/antro.v3i2.8791

${ }^{6}$ Hartini, Agnesia., Linda, Veronoka. (2017). Pembukuan Kasus Hukum Adat Sebagai Upaya Mengkonsistenkan Sanksi Adat Bagi Masyarakat Di Dusun Empaong Kecamatan Sekadau Hulu Kabupaten Sekadau. Jurnal PEKAN, 2 (1), 33-43. https://doi.org/10.31932/jpk.v2i1.195
}

$$
\text { 3|S A S I Vol. } 27 \text { No.1, Januari - Maret } 2021
$$


Sutrisno Purwohadi Mulyono mengatakan: Dengan berperannya hukum adat, warga masyarakat merasa turut bertanggungjawab terhadap terselenggaranya system pemerintahan Desa. Namun seiring dengan kebijakan pembangunan hukum nasional di Indonesia, terkadang hukum adat terbengkalai. ${ }^{7}$

Rini Apriyani, mengatakan: Berbagai lingkungan masyarakat adat di Kalimantan Timur dan Kalimantan Utara sanksi terkait hukum pidana adat seharusnya hanya berlaku pada beberapa perbuatan tertentu serta tidak berlaku untuk setiap orang. Pada kenyataannya belum terdapat kepastian hukum berkaitan dengan pemberian sanksi pidana adat tersebut. Selain itu ternyata sulit untuk merealisasikan aturan hukum pidana adat ditengah masyarakat adat. Hal ini disebabkan karena pemahaman masyarakat mengenai keberadaan hukum nasional Indonesia serta cukup beratnya sanksi adat yang dijatuhkan berkaitan tindak pidana adat. ${ }^{8}$

Nyoman Serikat Putra Jaya, mengatakan tentang pengakuan dan penghormatan serta pemberian tempat pada hukum adat, yang tidak hanya didasarkan pada undang-undang sebagai sumber hukum untuk menyatakan sebuah perbuatan sebagai tindak pidana. ${ }^{9}$

Berbeda dengan penelitian yang dilakukan peneliti, yaitu : Lokasi yang berbeda, teori yang digunakan, serta tujuan dari pelaksanaan tradisi yang diselenggarakan oleh masyarakat Misool Kepulauan Raja Ampat yang menimbulkan denda adat, dimana menggunakan ikan dan kerang laut sebagai media denda pada tradisi serta dalam rangka menjaga keseimbangan moral dengan penerapan sanksi adat terhadap pelaku penghinaan.

Landasan teoritis pada penelitian ini adalah sebagai berikut : Durkheim dalam Betty R. Scharf mengatakan : Solidaritas mekanik merupakan solidaritas yang dikukuhkan oleh "hakhak sakral" dalam masyarakat yang bersangkutan ${ }^{10}$. Lebih lanjut dikatakan : Solidaritas mekanik bersifat tetap namun demikian Ia memiliki arti sangat penting karena berdasarkan kesukuan, kesamaan nilai, serta lambang inilah difrensiasi itu dapat berkembang tanpa menimbulkan perpecahan ${ }^{11}$.

Berkaitan dengan Fungsionalis Struktur, Redcliffe-Brown dalam Chris Jenks, mengatakan: Struktur sosial yang dipandang sebagai suatu jaringan yang terbentuk dari hubungan-hubungan sosial yang mencakup kelompok, kategori, kelas serta peran-peran sosial yang keberadaannya tak mudah berubah ataupun hilang ${ }^{12}$. Chris Jenks mengasumsikan: tiaptiap system struktur sosial merupakan sebuah unit fungsional yang mampu memelihara dirinya sendiri, berfungsi memelihara keseimbangan, serta harmonis, disinilah letaknya keunggulan kesaling terhubungan ${ }^{13}$.

Ter Haar, dalam Bushar Muhammad, mengatakan: Pada wilayah Indonesia dari tingkat rakyat jelata, terdapat pergaulan hidup di dalam golongan-golongan yang memiliki tingkahlaku sebagai kesatuan terhadap dunia luar, lahir dan batin. Golongan-golongan ini memiliki tata susunan yang tetap dan kekal, dan orang-orang yang berada pada golongan itu mengalami kehidupan dalam golongan sebagai hal yang wajar, hal menurut kodrat alam. Tidak ada seorangpun dari mereka yang memiliki pikiran untuk memungkinkan pembubaran golongan tersebut. Golongan manusia ini mempunyai pengurus sendiri dan mempunyai harta benda, milik keduniaan dan milik gaib. Golongan-golongan demikianlah yang bersifat persekutuan

\footnotetext{
7 Mulyono, Sutrisno Purwohadi. (2014). Kebijakan Sinoptik Penerapan Hukum Adat Dalam Penyelenggaraan Pemerintahan. Jurnal Yustisia, 3 (2), 68-76. https://doi.org/10.20961/yustisia.v3i2.11096

8 Apriyani, Rini. (2018). Keberadaan Sanksi Adat Dalam Penerapan Hukum Pidana Adat. Jurnal Hukum Prioritas, 6 (3), 227-246. https://trijurnal.lemlit.trisakti.ac.id/prioris/article/view/3178

9 Jaya, Nyoman Serikat Putra. (2016). Hukum (Sanksi) PidanaAdat Dalam Pembaharuan Hukum Pidana Nasional. Masalah-Masalah Hukum, 45 (2), 123-130. https://doi.org/10.14710/mmh.45.2.2016.123-130

10 Scharf, Betty R. (2004). Sosiologi Agama. Jakarta: Prenada Media. h. 22.

11 Ibid. h.23

12 Jenks, Chris. (2013). Cultur, Studi Kebudayaan. Yogyakarta: Pustaka Pelajar. h. 54

13 Ibid. h.54-55
}

$$
\text { 4|SASI Vo1.2 } 7 \text { No.1, Januari-Maret } 2021
$$


hukum ${ }^{14}$. Lebih lanjut dikatakan: Struktur masyarakat menentukan sistem (struktur) hukum yang berlaku di masyarakat. Istilah hukum adat merupakan terjemahan dari istilah bahasa Belanda: adatrecht dan kata adat berasal dari bahasa Arab, yang memiliki arti: kebiasaan ${ }^{15}$.

Max Weber dalam Bryan S. Turner: mendekati budaya berkaitan dengan cara-cara budaya menempatkan tujuan serta tindakan-tindakannya tersusun bukan hanya melalui kepentingan, akan tetapi juga melalui norma ${ }^{16}$. Geertz dalam Chris Jenks, mengatakan: Pendekatan Mentalik simboliknya, banyak bertumpu pada deskripsi tentang sesuatu yang dipandang sebagai lapislapis mediasi, seperti suasana hati, motivasi dan konsepsi, diantara system-sistem symbolsimbol dan berbagai faktualitas kehidupan kesehariannya ${ }^{17}$. Mary Douglas dalam F.W. Dillistone, mengatakan: Natural Symbols memberikan kesaksian tentang nilai dari corak tertentu bentuk-bentuk ritual dalam membawakan koherensi dan stabilitas kepada masyarakat, kedudukan dan batas disimbolkan dengan tepat oleh ciri-ciri tubuh ${ }^{18}$. Langer dan Geertz dalam F.W. Dillistone, mengatakan: setiap tindakan, objek, peristiwa, hubungan atau sifat yang dapat berperan sebagai wahana suatu konsepsi, dan konsepsi itu merupakan"makna" simbol. Dengan demikian penapsiran kebudayaan pada dasarnya adalah penafsiran simbol-simbol ${ }^{19}$. Bourdieu dan Wacquant dalam Ritzer George dan Goodman J. Douglas mengatakan: "Negara sebagai tempat bertarung memperebutkan monopoli atas kekerasan simbolik. Ini merupakan bentuk "lunak" dari kekerasan-kekerasan yang digunakan terhadap agen sosial dalam keterlibatannya" 20 .

Michele Lamont dalam Bryan S. Turner, mengatakan: Menunjukkan bagaimana para pelaku menciptakan dan mempertahankan makna-makna sebagai suatu cara untuk menerima, mengatur, dan menolak sesama manusia, melampaui dan melawan urgensi dari struktur sosial ${ }^{21}$. Sejalan dengan itu, Gary Fine dalam Bryan S. Turner, mengatakan: kelompok-kelompok kecil mengembangkan serangkaian makna (kebiasaan, keyakinan dan pengetahuan), yang unik dan mendasari pemahaman bersama serta mengembangkan interaksi dan tindakan lebih lanjut ${ }^{22}$.

\section{B. METODE PENELITIAN}

Merupakan penelitian deskriptip kualitatif menggunakan paradigma fenomenologis Sosial. Penelitian ini memusatkan perhatian pada makna dan pengalaman subjektif sehari-hari, yang bertujuan untuk menjelaskan bagaimana objek dan pengalaman tercipta secara penuh makna dan dikomunikasikan dalam kehidupan sehari-hari. Setting penelitian di kepulauan Raja Ampat Distrik Misool Barat. Instrumen kunci dalam penelitian adalah masyarakat Misool Barat, pemimpin adat di Misool Barat serta peneliti sendiri. Sumber data untuk menganalisis permasalahan penelitian diperoleh dari dua sumber yaitu : data primer dan data sekunder. Melakukan pencarian data tertulis dengan jalan mendapatkan data yang dimaksud melalui tehnik Studi Kepustakaan. Penelitian ini berlangsung dilokasi penelitan (lapangan Penelitian) di Distrik Misool Barat Kepulauan Raja Ampat. Melakukan observasi partisipatoris yang pasif, dilakukan juga In-depth Interview. Menganalisa data dengan cara membagi kedalam tiga bagian: pertama dengan cara melakukan Reduksi Data, kedua melakukan Data Display (Penyajian Data), ketiga yaitu Conclusion Drawing/verification : penarikan kesimpulan dan verifikasi.

14 Muhammad, Bushar. (2006). Azas-Azas Hukum Adat, Suatu Pengantar. Jakarta: Pradnya Paramita. h. 34.

15 Ibid. h. 1-3

16 Turner, Bryan S. (2012). Teori Sosial Dari Klasik Sampai Postmodern. Yogyakarta, Pustaka Pelajar. h.649

17 Jenks, Chris. Op.Cit. h. 88

18 Dillistone, F.W. (2002). Daya Kekuatan Simbol, The Power Of Symbols, Yogyakarta: Kanisius. h.109

19 Ibid. h. 116

20 Ritzer, George., Goodman, Douglas J. (2011). Teori Sosiologi Modern. Jakarta: Kencana Prenada Media Group. h.526

21 Turner, Bryan S. Op.Cit. h. 647.

22 Ibid. h. 650.

$$
\text { 5|SASI Vo1. } 27 \text { No.1, Januari-Maret } 2021
$$




\section{PEMBAHASAN}

\section{Model Pelaksanaan Tradisi Famari Di Distrik Misool Barat, Kepulauan Raja Ampat}

Salah satu tradisi yang hampir punah di Papua Barat kepulauan Raja Ampat adalah tradisi Famari yang merupakan salahsatu tradisi yang menyebabkan denda adat bagi masyarakat Distrik Misool kepulauan Raja Ampat akibat dari merendahkan satu kelompok dengan kelompok lainnya sehingga menimbulkan sanksi adat yang diberikan kepada kelompok yang menghina tersebut. Tradisi ini telah berjalan sejak zaman dahulu dan dilaksanakan secara turun temurun oleh masyarakat Distrik Misool Barat kepulauan Raja Ampat. Asal muasal tradisi Famari yang berakibat denda adat tersebut merupakan hukum adat yang diciptakan sejak dahulu oleh para leluhur masyarakat Distrik Misool Barat, kepulauan Raja Ampat dalam rangka menciptakan ketertiban dan keselarasan hidup masyarakat, dimana didalamnya terdapat nilainilai universal seperti asas gotong royong, fungsi sosial manusia, dan milik dalam masyarakat, asas persetujuan sebagai kekuasaan umum, asas perwakilan dan permusyawaratan dalam sistim pemerintahan yang ada sehingga kerukunan diantara warga dapat tercipta.

Dalam kehidupan masyarakat tradisional sangat menghargai apa yang dinamakan Resam, Peresaman, Folksway dan Mores, dimana dalam masyarakat tradisional, hal-hal yang bersifat tabu menimbulkan konsekwensi terhadap si pelanggar tersebut. Dalam masyarakat tradisional hukum adat diberlakukan dan ditegakkan, segala hal yang berkaitan dengan denda adat ataupun sanksi adat diatur dalam hukum adat, yang mengatur tata kehidupan masyarakat adat. Munculnya sebuah tradisi biasanya ada penyebabnya, berupa masalah-masalah yang timbul dalam masyarakat tradisional, sehingga masyarakat tradisional membuat hukum untuk mengatur tatanan kehidupan masyarakat dan memberlakukan tradisi sebagai sesuatu yang sakral bagi masyarakat adat. Tradisi Famari pada masyarakat adat Distrik Misool Barat kepulauan Raja Ampat dimana kemunculannya memiliki sebab-sebab tertentu. Tradisi Famari diciptakan dalam rangka mengembalikan keseimbangan moral agar menimbulkan kesadaran kolektif dari setiap kelompok masyarakat adat dengan sanksi yang ada didalamnya, untuk menetralisir berbagai perbedaan-perbedaan dalam masyarakat dengan menerapkan tradisi Famari yang memiliki arti sangat penting karena berdasarkan kesukuan, kesamaan nilai, dan lambang inilah difrensiasi itu dapat berkembang tanpa menimbulkan perpecahan dalam masyarakat adat di Distrik Misool Barat kepulauan Raja Ampat.

Walaupun terdapat kemiripan suatu tradisi dari daerah yang satu dengan daerah yang lain di Nusantara, akan tetapi ada ciri tersendiri yang dimiliki sebuah tradisi yang membedakan dengan daerah lainnya, misalnya yang berkaitan dengan waktu pelaksanaan tradisi yang dilakukan sekelompok masyarakat adat untuk melaksanakan tradisi. Serangkaian tata cara yang berkaitan dengan waktu pelaksanaan tradisi berperan penting dalam pelaksanaan tradisi. Waktu pelaksanaan tradisi Famari pada masyarakat Distrik Misool Barat tidak melihat waktu kapan harus dilaksanakan, dimana dengan pelaksanaan tradisi ini mampu menyatukan warga masyarakat adat Distrik Misool Barat kepulauan Raja Ampat khususnya yang beragama Islam yang saling berselisih sehingga muncul perdamaian dan menyadarkan kelompok masyarakat agar tidak saling merendahkan yang dapat menimbulkan ketersinggungan, dalam rangka menyatukan kembali rakyat dan memperkuat struktur. .

Diwilayah Timur Indonesia umumnya bentuk dari denda adat ada yang berupa piring adat, Gong peninggalan Portugis/Belanda, Meriam V.O.C, emas, Manik-manik, piring gantung (piring antik), binatang ternak dan lain sebagainya yang harus dibayarkan oleh si pelanggar adat. Akan tetapi benda-benda unik yang tertulis diatas selain ternak untuk saat ini sudah sulit untuk didapat, sehingga masyarakat merubahnya kebentuk lainnya yaitu uang sebagai alat pembayaran yang sah di Negara ini sebagai pengganti denda adat. Begitu pula dengan tradisi Famari yang ada pada masyarakat Misool Barat kepulauan Raja Ampat yang menyebabkan denda adat pada masyarakat yang melanggarnya, mengalami perubahan bentuk pembayaran denda adat. Bentuk denda dalam tradisi Famari tidak tertulis dan ditetapkan berdsarkan kesepakatan sehingga pembayaran tidak mengecewakan dan diberikan berdasarkan kesadaran

$$
\text { 6|SASI Vo1. } 27 \text { No.1, Januari - Maret } 2021
$$


atau keinginan bersama, dan ini merupakan itikad sekelompok masyarakat adat yang melaksanakan tradisi Famari tersebut, dengan niat menghindari perselisihan diantara kelompok warga masyarakat adat di Distrik Misool Barat kepulauan Raja Ampat khususnya yang beragama Islam.

Keikutsertaan orang dalam sebuah tradisi yang menimbulkan sanksi adat, terkadang telah ditentukan jumlahnya, sehingga terkadang tidak semua masyarakat yang ada dalam sebuah Kampung atau kawasan dapat mengikuti tradisi tersebut, dimana terkadang ada batasan dan aturan yang dibuat untuk keikutsertaan orang dalam sebuah tradisi. Batasan tersebut telah disepakati sebelumnya oleh pihak-pihak yang bertikai. Begitu pula halnya dengan tradisi yang berkaitan dengan masalah mores, dimana untuk dapat berpartisipasi biasanya telah ditentukan sebelumnya, sehingga tidak semua orang dapat ikut serta dalam sebuah proses kegiatan yang berkaitan dengan tradisi tersebut. Tradisi Famari yang ada di Distrik Misool Barat kepulauan Raja Ampat berkaitan dengan pelanggaran yang menyebabkan sanksi adat. Biasanya yang ikut serta masih memiliki hubungan kekerabatan dalam bentuk Kindred. Jumlah masyarakat yang dapat mengikuti tradisi Famari tidak terdapat batasan yang jelas, hanya saja diperuntukkan bagi orang yang telah remaja atau dewasa, terkadang hanya bagi kaum tertentu misalkan laki-laki mengundang perempuan atau sebaliknya dari kedua belah pihak yang bertikai untuk dilibatkan secara kelompok (massal), disamping itu turut diundang pula para tokoh masyarakat seperti Raja Misool Barat, Jajao, Kapitan, Imam, Hakim Sara untuk dilibatkan secara individu sebagai saksi dalam tradisi Famari. Tradisi ini melibatkan banyak orang dalam pelaksanaannya dengan mengundang berbagai pihak baik yang bertikai maupun saksi.

Setiap tradisi yang berkaitan dengan hukum adat dalam masyarakat tradisional, biasanya terdapat konsekwesnsi yang berupa sanksi adat dalam penerapannya, baik berupa tindakan yang berhubungan dengan pembayaran denda adat atau yang berkaitan dengan sanksi sosial lainnya misalkan dikucilkan dari kelompok masyarakat adat, dan masih banyak lagi model sanksi adat yang timbul akibat adanya hukum adat yang harus dilaksanakan bagi si pelanggar adat, yang dapat menimbulkan efek jera bagi si pelanggar sanksi. Tradisi Famari yang ada pada masyarakat adat Distrik Misool Barat kepulauan Raja Ampat, terdapat denda adat yang diberikan sebagai sanksi dalam tradisi ini bila tidak mampu menghabiskan makanan yang telah disediakan oleh kelompok yang melaksanakan tradisi kepada kelompok yang melakukan pelanggaran, dimana tehnik pembayaran denda adat serta besaran denda diatur oleh tetua adat masyarakat yang bersangkutan. Tehnik pembayaran denda adat oleh masyarakat adat dalam tradisi Famari dilakukan setelah berlangsungnya pesta, dimana pembayaran dilakukan atas dasar kesepakatan antara si penuntut dan si pelanggar adat dimana pembayaran dirasakan tidak memberatkan kedua belah pihak yang bertikai dengan intinya adalah tetap menjaga tali persaudaraan, dimana diantara masyarakat Misool Barat umumnya masih memiliki hubungan kekerabatan walaupun berbeda Kampung.

Pelaksanaan sebuah tradisi yang mengaitkan berbagai elemen dalam masyarakat tradisional, biasanya dilakukan dengan jalan mengundang berbagai elemen masyarakat tradisional untuk dapat hadir dan berpartisipasi dalam kegiatan tersebut, lain halnya dengan tradisi yang dilakukan oleh individu dalam masyarakat tradisional yang hanya dilakukan oleh orang perorang. Tradisi yang besar dibutuhkan kesiapan khusus dalam pelaksanaannya. Untuk mengundang tokoh adat, tokoh agama, terdapat tata cara yang digunakan oleh masyarakat adat setempat. Begitu pula halnya dengan pelaksanaan tradisi Famari yang ada pada masyarakat adat Distrik Misool Barat kepulauan Raja Ampat, dimana dalam tradisi ini bukan hanya kelompok yang bertikai, tetapi juga mengundang tokoh adat dan tokoh agama setempat untuk dapat menjadi saksi dalam kegiatan tradisi Famari, sehingga dikemudian hari tidak menimbulkan pertikaian adat. Masyarakat Misool Barat ketika diundang dalam sebuah tradisi yang dilaksanakan secara bersama, walaupun tanpa adanya undangan resmi berupa surat undangan seperti halnya di kota besar, mereka akan datang, dan melibatkan diri baik secara

$$
\text { 7|SASI Vo1. } 27 \text { No.1, Januari - Maret } 2021
$$


individu, atau kelompok (massal), untuk ikut serta dalam kegiatan Famari. Akan tetapi ketika berhalangan, biasanya disampaikan pada saat si pengundang datang, kecuali halangan yang secara mendadak pada hari dilaksanakannya tradisi Famari.

Setiap tradisi yang dilaksanakan tidak terlepas dari apa yang disebut dengan simbol. Simbol yang melekat dalam sebuah tradisi dapat berupa, benda-benda yang digunakan dalam tradisi. Dalam melaksanakan tradisi biasanya menggunakan berbagai perangkat/peralatan dalam pelaksanaannya, dimana perangkat merupakan simbol yang melekat erat dalam sebuah tradisi. Penggunaan prangkat ini merupakan sesuatu yang harus dilakukan demi kelancaran pelaksanaan tradisi tersebut. Begitu pula dengan pelaksanaan tradisi Famari yang ada di Distrik Misool Barat, menggunakan berbagai peralatan dalam pelaksanaan tradisi Famari. Berbagai perlengkapan yang digunakan dalam tradisi Famari diantaranya: Pinang sirih dan rokok, ini merupakan alat pemersatu, dan juga sebagai alat dalam hal penerimaan tamu yang datang yang merupakan simbol yang memiliki makna didalamnya yang dapat ditafsirkan secara natural yang memberikan kesaksian tentang nilai penghormatan kepada tamu baik dari luar Misool Barat maupun dari dalam yang merupakan keluarga, dan sebagai alat pemersatu serta mampu menjadi lambang silaturahmi diantara warga masyarakat di Distrik Misool Barat kepulauan Raja Ampat.

\section{Dampak dan Cara Yang Digunakan Masyarakat Adat Dalam Mempertahankan Tradisi Famari Di Distrik Misool Barat, Kepulauan Raja Ampat}

\section{a. Dampak Dari Masyarakat Adat Mempertahankan Tradisi Famari}

Tradisi Famari yang diterapkan oleh masyarakat adat di Distrik Misool Barat, dimana masyarakat yang merasa diri masih terikat dengan hubungan persaudaraan, dalam rangka menghindari diri dari tabiat yang berkaitan dengan merendahkan orang lain atau kelompok lain yang masih bersaudara. Tradisi Famari diciptakan salah satunya adalah untuk menghindarkan dari tabiat masyarakat merendahkan kelompok masyarakat lainnya, dimana terdapat sanksi sebagai hukuman orang yang bersalah dan dengan itu mengembalikan keseimbangan moral dalam masyarakat adat.

Tradisi Famari yang ada pada masyarakat Distrik Misool Barat kepulauan Raja Ampat merupakan salah satu penerapan hukum adat yang secara lisan ditatati dan dilakukan oleh masyarakat adat, dimana tradisi ini berkembang secara turun temurun. Tradisi yang muncul biasanya untuk menciptakan kestabilan dalam masyarakat tradisional agar dapat mempertahankan tatanan hidup masyarakat tradisional serta tidak menimbulkan kesalahpahaman yang dapat menimbulkan bentrok antara satu Kampung akibat penghinaan yang dilontarkan seseorang terhadap orang lain, dalam Famari terdapat hukum adat yang mengatur nilai universal seperti asas gotong royong, fungsi sosial manusia, dan milik dalam masyarakat, asas persetujuan sebagai kekuasaan umum, asas perwakilan dan permusyawaratan dalam mengambil keputusan karena dihadiri oleh tokoh adat masyarakat agar tercipta kerukunan diantara warga masyarakat adat yang sedang bertikai, sehingga tidak menimbulkan perpecahan diantara warga. Pada masyarakat kepulauan Raja Ampat terdapat tradisi yang mulai hilang dan jarang dilaksanakan akibat dari perkembangan zaman. Salah satu tradisi yang masih tersisa di Distrik Misool Barat adalah Famari, untuk dapat mempertahankan tradisi dibutuhkan kesadaran dari semua pihak agar dapat melestarikannya.

Tradisi ini tetap dilaksanakan adalah untuk melestarikan budaya masyarakat adat khususnya masyarakat adat Distrik Misool Barat kepulauan Raja Ampat yang beragama Islam sebagai identitas bagi kelompok masyarakat adat, dimana terdapat nilai yang tinggi dalam usaha untuk mempertahankan nilai agar tidak merendahkan orang lain. Tradisi Famari bukan hanya menghukum orang berdasarkan hukum adat masyarakat Misool Barat sehingga menimbulkan efek jera terhadap si pelanggar, juga merupakan penyelesaian masalah yang diambil dengan cara kekeluargaan, yang sering dilakukan oleh masyarakat adat, penyelesaian masalah tidak dilakukan dengan pertikaian, masyarakat menganggap dalam satu kawasan masih kental dengan hubungan persaudaraan, penyelesaian permasalahan diambil dengan musyawarah

$$
\text { 8|SASI Vo1. } 27 \text { No.1, Januari - Maret } 2021
$$


mufakat, agar tidak muncul perpecahan diantara masyarakat adat. Tradisi Famari mampu menjaga persaudaraan antar sesama masyarakat dimana konsep hubungan dan saling tidak terpisah antara individu dan masyarakat adalah dilahirkan kembar. "Kesadaran sosial tidak dapat diasingkan dari kesadaran diri". Individu adalah suatu abstrak yang tidak diketahui melalui pengalaman, dan juga dengan masyarakat apabila dianggap sebagai suatu yang berlainan pada individu. Kehidupan adalah keseluruhan organik dalam sebuah masyarakat termasuk masyarakat adat di Distrik Misool Barat kepulauan Raja Ampat.

\section{b. Cara Yang Digunakan Masyarakat Adat Dalam Mempertahankan Tradisi Famari}

Norma adat yang muncul dalam sebuah tradisi merupakan sebuah pembiasaan dari masyarakat adat sebelumnya dan dilakukan secara turun temurun. Tradisi Famari dilaksanakan karena masyarakat adat memiliki perasaan malu/tabu ketika direndahkan oleh orang lain atau sekelompok orang, sehingga berusaha untuk memperbaiki nama baiknya di depan orang banyak, akan tetapi tata cara penyelesaiannyapun tidak menimbulkan pertikaian antara satu kelompok dengan kelompok lainnya, karena masyarakat adat merasa bersaudara antara satu Kampung dengan Kampung lainnya (Mafatanon/bersaudara).

Kebiasaan masyarakat menerapkan tradisi Famari dalam memelihara tradisi yang berlangsung hingga kini dalam rangka mengembangkan kebudayaan masyarakat yang ada di Distrik Misool Barat kepulauan Raja Ampat yang berkaitan dengan hukum adat ketika terjadi penghinaan dalam bentuk pemberian makanan kepada seseorang atau sekelompok orang. Berbagai tradisi yang ada di kepulauan Raja Ampat khususnya di Distrik Misool Barat lambat laun juga akan mengalami hal yang sama, yaitu mengalami degradasi, begitu pula dengan tradisi Famari, dimana tradisi ini berisikan tentang bagaimana sanksi yang diberikan untuk para pelanggar, dilakukan agar dapat terpelihara sikap saling menghormati antara seseorang dengan orang lain atau sekelompok orang dengan orang lain. Tradisi ini mulai jarang dilakukan oleh masyarakat, dimana tidak semua orang di Distrik Misool Barat paham tentang tradisi ini, namun hanya orang tertentu saja yang memahaminya terutama tokoh adat yang ada di beberapa Kampung di Distrik Misool Barat kepulauan Raja Ampat.

Masyarakat adat mempertahakan tradisi yang masih diingat dengan jalan melaksanakannya berbagai tradisi yang merupakan keyakinan, simbol ekspresif atau pola nilai, dimana berbagai tradisi berkaitan dengan nilai-nilai yang terkandung di dalamnya. Baik tidaknya sebuah tradisi yang diterapkan dalam sebuah masyarakat tradisional bergantung pada respon masyarakat adat tentang tradisi yang dilaksanakan. Apakah masyarakat mau menerima tradisi tersebut dan mempertahankan tradisi sebagai warisan budaya masyarakat setempat atau bahkan menghindari tradisi sehingga tidak mampu untuk dipertahankan dan dilaksanakan oleh masyarakat tradisional. Tradisi Famari dianggap penting dalam menghindari sifat sombong yang dapat merendahkan orang lain terlebih saudaranya sendiri setiap warga yang ada di Distrik Misool Barat memiliki hubungan kekerabatan yang erat satu sama lainnya, serta untuk melestarikan budaya masyarakat adat, dimana dalam tradisi terdapat makna yang sangat baik dalam mempertahankan persatuan, serta menjadi motivasi masyarakat, dan memiliki pesan positif yang terkandung didalamnya sehingga tradisi ini tetap dilaksanakan. Tradisi Famari yang ada di Distrik Misool Barat kepulauan Raja Ampat, dimana tidak semua warga dapat melibatkan komponen masyarakat di dalam Kampung. Tradisi ini biasanya dilakukan berdasarkan marga/fam/klain dalam sebuah Kampung dan mengundang Kampung lainnya yang bertikai, disamping itu yang diundang dalam tradisi ini adalah Tokoh adat, tokoh agama yang ada dan masyarakat yang bersangkutan. Sehingga biasanya yang diundang berdasarkan hubungan kekerabatan saja. Pelaksanaan tradisi Famari melibatkan berbagai elemen masyarakat adat berpartisipasi sebagai saksi dalam kegiatan dan untuk mengatasi permasalahan yang timbul sehingga dapat diselesaikan dengan baik melalui musyawarah dimana dalam musyawarah dibutuhkan mufakat dari sesama pihak yang bertikai. Datangnya tokoh adat dan

$$
\text { 9|SASI Vo1. } 27 \text { No.1, Januari - Maret } 2021
$$


tokoh masyarakat dalam kegiatan tersebut sebagai saksi maka akan mengikat dalam bentuk hukum adat dimana terdapat denda yang harus dibayarkan dalam tradisi.

\section{P E N U T U P}

Asal muasal tradisi Famari merupakan hukum adat yang diciptakan oleh leluhur masyarakat Misool Barat kepulauan Raja Ampat dalam menciptakan ketertiban, di dalamnya terdapat nilai universal seperti asas gotong royong, fungsi sosial, dan milik dalam masyarakat, persetujuan sebagai kekuasaan umum, asas perwakilan dan permusyawaratan dalam sistim pemerintahan adat. Tradisi Famari diciptakan dalam mengembalikan keseimbangan moral agar menimbulkan kesadaran kolektif masyarakat, untuk menetralisir perbedaan, memiliki arti penting berdasarkan kesukuan, kesamaan nilai, dan lambang dapat berkembang tanpa menimbulkan perpecahan dalam masyarakat. Pelaksanaan tradisi Famari tidak melihat waktu kapan dilaksanakan, tradisi mampu menyatukan masyarakat adat khususnya yang beragama Islam yang berselisih sehingga muncul perdamaian dan menyadarkan masyarakat agar tidak saling merendahkan yang menimbulkan ketersinggungan. Denda dalam tradisi Famari berdasarkan kesepakatan. Tradisi Famari diperuntukkan bagi remaja atau dewasa, terkadang hanya bagi kaum tertentu misalkan laki-laki mengundang perempuan atau sebaliknya dari kedua belah pihak yang bertikai dilibatkan secara kelompok (massal), melibatkan tokoh adat sebagai saksi yang mengikat dalam bentuk hukum adat. Pembayaran denda dilakukan setelah berlangsungnya tradisi. Perlengkapan yang digunakan dalam tradisi Famari diantaranya : Pinang sirih dan rokok, merupakan alat pemersatu dalam penerimaan tamu, merupakan simbol yang memiliki makna di dalamnya yang dapat ditafsirkan secara natural, memberikan kesaksian tentang nilai penghormatan kepada tamu baik dari luar Misool Barat maupun dari dalam, mampu menjadi lambang silaturahmi antar warga. Tradisi ini dilaksanakan adalah untuk melestarikan budaya masyarakat adat khususnya masyarakat adat yang beragama Islam sebagai identitas bagi kelompok masyarakat adat, terdapat nilai-nilai yang tinggi dalam usaha mempertahankan nilai tidak merendahkan orang lain.

Saran dari peneliti adalah sebagai berikut: Dibutuhkan kesadaran masyarakat untuk mengembangkan tradisi Famari dalam kehidupan masyarakat agar tidak hilang ditelan zaman. Dibutuhkan adanya peran serta pemerintah daerah untuk mengembangkan budaya di Misool Barat sebagai salahsatu bentuk kepedulian pemerintah sebagai daya tarik wisata diwilayah tersebut. Menjadikan tradisi Famari sebagai bentuk kepedulian masyarakat dalam mengejawantahkan pandangan hidup masyarakat yang patut ditiru dan dikembangkan dalam menjaga persatuan dan persaudaraan dengan tidak merendahkan salahsatu golongan dalam masyarakat adat Misool Barat Kepulauan Raja Ampat.

\section{DAFTAR PUSTAKA}

\section{Jurnal}

[1] Apriyani, Rini. (2018). Keberadaan Sanksi Adat Dalam Penerapan Hukum Pidana Adat. $\begin{array}{lllll}\text { Jurnal Hukum } & \text { Prioritas, } & 6 & \text { (3), }\end{array}$ https://trijurnal.lemlit.trisakti.ac.id/prioris/article/view/3178.

[2] Dewantara, Asep. (2013). Peran Elit Masyarakat: Studi Kebertahanan Adat Istiadat di Kampung Adat Urug Bogor, Buletin Al-Turas, 19 (1), 89-117. https://doi.org/10.15408/bat.v19i1.3703.

[3] Humaeni, Ayatullah. (2015). Tabu Perempuan Dalam Budaya Masyarakat Banten. Jurnal Humaniora, 27 (2), 174-185. https://doi.org/10.15408/bat.v19i1.3703.

[4] Hartini, Agnesia., Linda, Veronoka. (2017). Pembukuan Kasus Hukum Adat Sebagai Upaya Mengkonsistenkan Sanksi Adat Bagi Masyarakat Di Dusun Empaong Kecamatan 
Sekadau Hulu Kabupaten Sekadau. Jurnal PEKAN, 2 (1), 33-43. https://doi.org/10.31932/jpk.v2i1.195.

[5] Harahap, Anwar Sadat., Hasibuan, Ahmad Laut., Siregar, Taufik. (2018). Kearifan Lokal Dalam bentuk Sanksi Hukum Bagi Pelanggar Pada Masyarakat Adat Batak Bagian Selatan. Anthropos: Jurnal Antropologi Sosial dan Budaya, 3 (2), 122-130. https://doi.org/10.24114/antro.v3i2.8791

[6] Hardiman, Yogi., Kotijah, Siti., Sina, La. (2019). Restorative Justice Terhadap Pelaku Tindak Pidana Ringan Yang Telah Diberi Sanksi Adat. Mulawarman Law Review. 14 (1), 29-43. https://doi.org/10.30872/mulrev.v4i1.48.

[7] Jaya, Nyoman Serikat Putra. (2016). Hukum (Sanksi) PidanaAdat Dalam Pembaharuan Hukum Pidana Nasional. Masalah-Masalah Hukum, 45 (2), 123-130. https://doi.org/10.14710/mmh.45.2.2016.123-130.

[8] Mulyono, Sutrisno Purwohadi. (2014). Kebijakan Sinoptik Penerapan Hukum Adat Dalam Penyelenggaraan Pemerintahan. Jurnal Yustisia, 3 (2), 68-76. https://doi.org/10.20961/yustisia.v3i2.11096.

[9] Rahman, Abdul., Jamhuri., Irwansyah. (2018), Sanksi Adat Bagi Pelaku Kekerasan Fisik Ditinjau Menurut Hukum Pidana Islam. Jurnal Petita, 3 (2), 137-144. https://doi.org/10.22373/petita.v3i2.49.

\section{Buku}

[10]Dillistone, F.W. (2002). Daya Kekuatan Simbol, The Power Of Symbols, Yogyakarta: Kanisius.

[11] Jenks, Chris. (2013). Cultur, Studi Kebudayaan. Yogyakarta: Pustaka Pelajar.

[12] Muhammad, Bushar. (2006). Azas-Azas Hukum Adat, Suatu Pengantar. Jakarta: Pradnya Paramita.

[13]Ritzer, George., Goodman, Douglas J. (2011). Teori Sosiologi Modern. Jakarta: Kencana Prenada Media Group.

[14] Scharf, Betty R. (2004). Sosiologi Agama. Jakarta: Prenada Media.

[15]Turner, Bryan S. (2012). Teori Sosial Dari Klasik Sampai Postmodern. Yogyakarta, Pustaka Pelajar. 